Nevşehir Bilim ve Teknoloji Dergisi TARGíd Özel Sayı 32-40 2016

DOI: 10.17100/nevbiltek.210959

URL: http://dx.doi.org/10.17100/nevbiltek.210959

\title{
Yumurta Tavuğu Rasyonlarına Sarımsak Tozu İlavesinin Yumurta, Kan, Karaciğer, But ve Göğüs Dokularında Bazı Antioksidan Enzimler Üzerine Etkisi
}

\author{
Şaban Çelebi, Adem Kaya*, Hatice Kaya \\ Atatürk Üniversitesi, Ziraat Fakültesi, Zootekni Bölümü, Erzurum
}

Öz

Bu çalışma, yumurta tavuğu karma yemlerine sarımsak tozu ilavesinin karaciğer, göğüs, but, kan ve yumurtada bazı antioksidan enzimlerin (Glutatyon peroksidaz (GSH Px), Süperoksit dismutaz (SOD), Glutatyon s-transferaz (GST) ve Katalaz (CAT)) düzeyleri üzerine etkilerini incelemek amacıyla yapılmıştır. Bu amaçla, 38 haftalık yaşta 96 adet Lohmann ırkı ticari yumurta tavuğu her biri 6 alt grup ve her alt grupta 4 hayvan olacak şekilde 4 ana gruba ayrılmış ve karma yeme sırasıyla; \%0, 2, 4 ve 6 seviyelerinde sarımsak tozu ilave edilerek oluşturulan rasyonlarla 12 hafta süreyle beslenmişlerdir. Deneme sonunda her gruptan şansa bağlı olarak 6 yumurta ve hayvan seçilmiş, hayvanlardan karaciğer, göğüs, but ve kan örnekleri alınarak bunlarda; GSH Px, SOD, GST ve CAT düzeyleri tespit edilmiştir. Rasyona sarımsak tozu ilavesi, yalnızca yumurta sarısı CAT düzeylerinde istatistiksel olarak önemli bulunmayan bir düşüşe neden olması dışında, incelenen tüm enzim düzeylerini ele alınan diğer tüm dokularda önemli derecede etkilediği $(\mathrm{P}<0.05)$, ve rasyona ilave edilen sarımsak tozu düzeyine paralel olarak ilgili enzim düzeylerini yükselttiği belirlenmiştir. Bu çalışma sonucunda; kanatlı hayvanların rasyonlarına sarımsak tozu ilavesi, dokularda antioksidan enzimlerin düzeylerini artırarak dokulardaki oksidasyonu azaltıp veya geciktirebileceği, bunun da insan beslenmesinde önemli bir yeri olan ve kolay bozulabilen beyaz etin raf ömrünün uzamasına katkıda bulunacağı, ayrıca doğal bir antibiyotik olan sarımsağın, hayvanların sağlıklarını olumlu yönde etkileyerek performansları üzerine olumlu katkıda bulunacağı söylenebilir.

Anahtar Kelimeler: Yumurta tavuğu, sarımsak tozu, antioksidan enzimler

\section{The Effect of Dietary Garlic Powder Supplementation on Some Antioxidant Enzyme Levels in Yolk, Blood, Liver, Chest and Thigh of Laying Hens}

\begin{abstract}
This study was conducted to investigate the effects of garlic powder at different levels into diets of laying hens on some antioxidant enzymes (Glutathion peroxidase (GSH Px), Superoxide dismutase (SOD), Glutahion s transferase (GST) and Catalase (CAT)) activities in liver, blood, chest, thigh and yolk. A total of 96 Lohmann White hens 38 weeks of age were allocated randomly four groups each formed six replicate cages as subgroups comprising of four hens. Treatment groups were fed diets supplemented with 0 , 2, 4 and 6\% garlic powder respectively from weeks 38 to 50. GSH-Px, GST, SOD and CAT levels increased $(\mathrm{P}<0.05)$ linearly with increasing level of feding garlic powder but, CAT levels decreased in only egg yolk. In conclusion, garlic powder supplementation into layer diets can decrease or delay the oxidation in tissues by increase antioxidant enzyme levels in these tissues. As this, can contribute to prolong storage time of easily perishable poultry meat that has important role in human nutrition. Also, the garlic which is a natural antioxidant is said to contribute positively by effecting the health of animal on its performance.
\end{abstract}

Keywords: Laying hens, garlic powder, antioxidant enzymes

*e-mail: akaya@atauni.edu.tr 


\section{Giriş}

Son 40-50 yıl içerisinde tavukçuluk sektöründeki bakım, besleme, 1slah ve özellikle biyoteknolojik gelişmeler, yüksek verimli hatların yetiştirilmesini sağlamıştır. Ancak, bu gelişmelerle birlikte hastalıklara karşı mukavemette azalma, yumurta kabuk kalitesinde düşme, stres faktörleri ve özellikle oksidatif strese duyarlılık yükselmiştir [1]. Oksidatif stres canlı organizmada doğal olarak gerçekleşen kimyasal reaksiyonlar sonucu oluşan serbest radikallerin, normalin üzerinde artmasıyla hücre ve dokularda hasara yol açmasıdır [2]. Serbest radikaller, arteroskleroz, nörodejeneratif hastalıklar, kanser, alerji, diyabet ve katarakt gibi birçok hastalığın patogenezinde rol oynayan ve bu nedenle son zamanlarda üzerinde en çok çalışılan konular arasında yer almaktadır. Serbest radikaller dış orbitallerinde bir veya daha fazla eşleşmemiş elektron taşıyan reaktif atom veya bileşiklerdir [3 ve 4]. Bu moleküller eksik elektronlarını paylaşabilmek için diğer moleküllerle hızla reaksiyona girerler. Bu radikallerle reaksiyona giren moleküllerin bir elektronu azaldığı için onlarda reaktif hale gelir ve bu reaksiyon zincirleme olarak devam eder [5]. Mitokondriyal, endoplazmik ve nüklear elektron transport sistemlerinde (stokrom D-450), peroksizomlarda, monosit ve nötrofillerin fagasitozu gibi normal metabolik olaylar sırasında bol miktarda serbest radikal üretilir. En sık rastlanan radikaller şunlardır: süperoksit anyonu $\left(\mathrm{O}_{2}^{-}\right)$, hidrojen peroksit $\left(\mathrm{H}_{2} \mathrm{O}_{2}\right)$, hidroksil radikali $\left(\mathrm{OH}^{-}\right)$, singlet oksijen $\left(\mathrm{O}_{2}\right)$, nitrik asit (NO), peroksil radikali (ROO), hidroperoksil radikali $\left(\mathrm{HO}_{2}\right)$ ve alkoksil radikalidir (RO) [6 ve 7]. Bu radikallerin oluşumunu ve meydana getireceği hasarı kontrol etmek ve önlemek için oraganizmada enzimik (SOD, GST, GSH-Px, CAT, GR) ve enzimik olmayan (Glutatyon, Vit E, Vit C, beta karoten, melatonin, üreat, sistein, seruloplazmin, transferin, miyoglobin, hemoglobin, metiyonin ve albümin) olmak üzere birçok antioksidan savunma mekanizması gelişmiştir [3 ve 8]. Eğer bu radikaller antioksidan savunma mekanizmasının kapasitesini aşarlarsa hücrelerin lipit, protein, DNA, karbonhidrat ve enzim gibi önemli bileşenlerinde hasara (oksidatif strese) neden olabilmektedirler. Lipitler, serbest radikal hasarına karşı en hassas yapılardır. Serbest radikaller yağ asitlerindeki doymamış bağlarla kolayca reaksiyona girerek lipidlerin peroksidasyonuna (LPO) neden olurlar ve bu reaksiyonlar engellenmediği takdirde kendiliğinden yürüyen zincirleme bir reaksiyona dönüşüp geri dönüşümsüz membran hasarlarına yol açmaktadırlar [9]. Hücre yüzeyinde bulunan hormon reseptörleri, DNA, Glukoz-6 fosfat dehidrojenaz ve $\mathrm{Na}^{+}, \mathrm{K}^{+}$, ATP az gibi enzimler lipit peroksidasyonu esnasında inaktif hale geçerler, böylece LPO hücrelerde dejeneratif, mutojenik ve karsinojenik bozulmalara neden olabilir [10].

Kanatlı hayvanlar normal fizyolojik şartlarda ürettikleri serbest radikalleri, enzimik ve enzimik olmayan antioksidan savunma sistemleri ile etkisizleştirebilmektedirler. Mesela, alfa tokoferol (Vit E) lipit peroksidasyon reaksiyonunu serbest radikal (oksidan) üreten basamağınaelektron sağlayıp lipit peroksidasyon zincirini kırarak $\mathrm{H}_{2} \mathrm{O}_{2}$ üretimini önlerken, GPx oluşmuş $\mathrm{H}_{2} \mathrm{O}_{2}$ radikalini suya $\left(\mathrm{H}_{2} \mathrm{O}\right)$ dönüştürmek suretiyle etkisiz hale getirir. Ancak stres faktörlerinin öne çıktığı bazı olumsuz durumlarda serbest radikal üretimi aşırı düzeyde artarak endojen antioksidan havuzunu tüketebilir. $\mathrm{Bu}$ gibi durumlarda kanatlı yemlerinde stabilitenin sağlanması ürünlerde oksidatif bozulmanın önlenmesi ve oksidatif stresin etkisinin azaltılması amacıyla, bu hayvanların yemlerine bir takım antioksidan bileşikler veya endojen antioksidan savunma sistemini destekleyen bazı yem katkı maddeleri katılabilmektedir. İște bunlardan biriside önemli doğal bir anti bakteriyel ve antioksidan özelliğe sahip olan sarımsaktır. Sarımsak (Allium sativum), Alliaceae (zambakgiller) familyasına dahil, Allium cinsinden bir soğanlı 
bitkidir. Anavatanının Orta Asya olduğu sanılmaktadır. Sarımsak germanyum ve selenyum bakımından zengin toprakları sever. Dünyanın çeşitli bölgelerinde 300-400 çeşit sarımsağın yetiştiği bilinmektedir. Sarımsağın sağlık üzerine olan olumlu etkisi 5000 yıldan daha fazla süreden beri bilinmektedir. Babiller, Mısırlılar, Frikeliler, Romalılar, Çinliler, Yunanlılar ve Hintliler tarafından ilaç olarak kullanıldığı bildirilmektedir [11-13]. Sarımsağın yapısı oldukça karışıktır. Sarımsağın \%35 kuru maddesinin; \%2630’unu fruktoz içeren karbonhidratlar, enzimler (alinaz, katalaz), \%33’ünü sülfürlü bileşikler, \%1.5,3.5'ini protein, \%1.5-2.1'ini serbest amino asit (arginin) ve \%1.5'ini lif oluştururken, sarımsağın lipit içeriği \%0.1-0.2 civarındadır. Sarımsak yüksek düzeyde $\mathrm{P}, \mathrm{K}, \mathrm{S}, \mathrm{Zn}$, orta düzeyde Se, A ve C vitaminlerini ve düşük düzeyde, $\mathrm{Ca}, \mathrm{Mg}, \mathrm{Mn}, \mathrm{Na}, \mathrm{Fe}$ ve B grubu vitaminleri içermektedir. Sarımsakta bulunan aktif bileşiklerin organosülfür bileşikleri olduğu bildirilmektedir [14]. Bu organosülfür bileşiklerinin başlıcaları, allin, allicin, s-allil sistein (SAC), allil profildisülfid, diallilsülfid, diallildisülfid, dialliltrisülfid, ajoene, allixin, allil mercaptan’lar ve allil metil sülfitlerdir [15].

Yumurta tavuklarının fizyolojileri gereği metabolizmalarının ruminantlardan daha yüksek olması, yüksek düzeyde yumurtlama fizyolojisi, bu hayvanları oksidatif strese yatkın hale getirmektedir. Bu çalışmada, yumurtlamanın yüksek olduğu dönemde (38. Hafta) yumurtacı tavuk karma yemine doğal bir antioksidan özelliğine sahip sarımsak tozu ilavesinin, antioksidan enzim düzeyleri üzerine etkisini incelemek amacıyla yapılmıştır.

\section{Materyal ve Metot}

\section{Hayvan Materyali, Deneme Gruplarının Oluşturulması ve Hayvanların Beslenmesi}

$\mathrm{Bu}$ araştırmanın hayvan materyalini, Atatürk Üniversitesi Ziraat Fakültesi Araştırma ve Uygulama Çiftliği Tavukçuluk Şubesi'nde bulunan 38 haftalık yaştaki Lohmann ırkı beyaz ticari yumurta tavuğu oluşturmuştur. Hayvanlar her biri altı alt grup ve her alt grupta dört hayvan bulunacak şekilde dört gruba ayrılmış ve tartılarak, üç katlı batarya tipi kafeslere (50x46x46 cm) şansa bağlı olarak dağıtılmıştır. Birinci grup besin madde kompozisyonu Tablo 1'de verilen bazal yemle (Kontrol), diğer gruplar ise bazal yemde bulunan arpa ile sırasıyla \%2 (S-2), 4 (S-4) ve 6 (S-6) düzeyinde sarımsak tozu ikame edilerek oluşturulan karma yemlerle 12 hafta boyunca beslenmişlerdir. Yem ve su ad-libitum olarak verilirken hayvanlara 16 saatlik aydınlatma sağlanmıştır.

Deneme sonunda her gruptan şansa bağlı olarak altı yumurta ve altı hayvan seçilerek kesilmiş ve hayvanlardan kan, karaciğer, göğüs ve but dokularından numuneler alınmıştır. Alınan kan örnekleri heparinli tüplere aktarılarak $3000 \mathrm{rpm}$ de $+4^{0} \mathrm{C}$ de $10 \mathrm{dk}$ santrifüj edilerek plazmaları ayrılmış ve karaciğer, but ve göğüs örnekleri ile birlikte analizler yapılıncaya kadar $-70^{\circ} \mathrm{C}$ de muhafaza edilmiştir. İlgili dokularda antioksidan enzimlerin analizler Aktaş [16]'ın bildirdiği yönteme göre yapılmıştır.

Tablo 1. Denemede kullanılan bazal yemin bileşimi ve kimyasal kompozisyonu (\%)

\begin{tabular}{lclc}
\hline Yem Maddeleri & Miktarı & Kimyasal Kompozisyonu & Miktarları \\
Mısır & 52.81 & Kuru Madde & 89.47 \\
Soya Küspesi & 18.13 & Ham Protein & 16.50 \\
Arpa & 6.00 & Ham Selüloz & 4.49 \\
Tam Yağlı Soya & 1.65 & Ham Kül & 11.70 \\
AyçiçeğiTohumu K. & 7.5 & HCL'de Çözünen Kül & 1 \\
Misır Gluten Unu & 2.04 & Ham Yağ & 4.88 \\
Soya Yağı & 1.60 & Lisin & 0.7
\end{tabular}




$\begin{array}{lllc}\text { Mermer Tozu } & 6.82 & \text { Metiyonin } & 0.33 \\ \text { Tuz } & 0.30 & \text { Kalsiyum } & 3.4 \\ \text { DCP 18 } & 2.65 & \text { Fosfor } & 0.7 \\ \text { D-L Metiyonun 99 } & 0.15 & & \\ \text { L-Lisin } & 0.10 & & 2720 \\ \text { Vit-Min } & 0.25 & \text { ME }(\mathrm{kcal} / \mathrm{kg}) & \end{array}$

Her 2 kg'da 12.000 IU Vitamin A, 2.500 IU Vitamin D3, 30 mg Vitamin E, 34 mg Vitamin K, 3 mg Vitamin B1, 6 mg Vitamin B2, $30 \mathrm{mg}$ Nicotin Amid, $10 \mathrm{mg}$ Cal.-D-Paln, $5 \mathrm{mg}$ Vitamin B6, $15 \mathrm{mg}$ Vitamin B12, $1.000 \mathrm{mg}$ Folik Asit, $50 \mathrm{mg}$ D-Biotin, $300 \mathrm{mg}$ Cholin, 50 mg Vitamin C, 80 mg Manganez, 60 mg Demir (Fe), 60 mg Çinko (Zn), 5 mg Bakır (Cu), 2 mg İyot (I), 0.5 mg Kobalt (Co), 150 mg Selenyum (Se)

\section{İstatistiksel Analiz}

Deneme gruplarına ait antioksidan enzimler ile ilgili değerlerin varyans analizleri ve önemli bulunan varyasyon kaynaklarına ait ortalamaların önemlilik kontrolü SPSS 10.0 [17] paket programının GLM ( Genel linear Model) prosedürüne göre yapılmıştır.

\section{Bulgular ve Tartış̧ma}

Yumurta tavuğu karma yemlerine sarımsak tozu ilavesinin, çeşitli dokularda bazı antioksidan enzimlerin aktiviteleri üzerine etkilerini incelemek amacıyla, deneme gruplarından alınan çeşitli dokulara (kan, karaciğer, göğüs, but ve yumurta) ait bazı antioksidan enzimler (GSH-Px, GST, SOD ve CAT) ile ilgili ortalama değerler ve varyans analiz sonuçları Tablo 2, Tablo 3, Tablo 4 ve Tablo 5 'te verilmiştir. Tablolar incelendiğinde yeme sarımsak tozu ilavesinin, yumurta sarısı katalaz düzeyi hariç ele alınan diğer tüm dokularda söz konusu antioksidan enzimlerin karma yeme ilave edilen sarımsak tozunun düzeyine paralel olarak yükseldiği görülmektedir. Tablo 2 incelendiğinde yeme sarımsak tozu ilavesinin incelenen tüm dokularda GST düzeyini önemli derecede yükselttiği $(\mathrm{P}<0.05)$ görülmektedir.

\begin{tabular}{|c|c|c|c|c|c|c|}
\hline Göğüs & $11.95^{\mathrm{c}}$ & $13.14^{\mathrm{b}}$ & $14.30^{\mathrm{a}}$ & $15.06^{\mathrm{a}}$ & 0.31 & 0.000 \\
\hline Serum & $39.01^{c}$ & $40.03^{\mathrm{bc}}$ & $40.84^{\mathrm{b}}$ & $43.25^{\mathrm{a}}$ & 0.50 & 0.000 \\
\hline Yumurta & 2.43 & 2.60 & 2.92 & 2.40 & 0.14 & 0.068 \\
\hline
\end{tabular}

GST, vücutta karaciğer, akciğer, böbrek, kas, meme, testisler ve kalın bağırsaklar ile plazma gibi tüm dokuların stozol ve membranlarında bulunmakta ve glutatyonun serbest radikaller, lipit peroksitler ve ksenobiyotiklerle konjugasyonunu sağlayarak hücreleri oksidatif zarara karşı korumakta ve böylece organizmayı oksidatif stresten kaynaklanan kalp, karaciğer, kas, kanser diyabet ve romatoid artrit gibi birçok patolojik durumlardan korunmasını sağlar [18-20]. Ratlar üzerine konuyla ilgili olarak çok sayıda çalışma mevcut olmasına rağmen gerek yumurta tavukları gerekse broylerler üzerine yürütülen araştırmaların sayısı oldukça sınırlı düzeydedir. Nitekim, Sheen ve ark. [21] sarımsak yağı ve bunun organosülfür bileşiklerinden Diallil sülfit (DAS) ve Diallil disülfit (DADS)'in rat diyetlerine ilavesinin (200 mg/kg) karaciğer ve serumda GTS, GSH-Px ve SOD seviyelerini önemli düzeyde artırdığını bildirmişlerdir. Yine aynı çalışmada, rat diyetlerine sırasıyla $0,30,80$ ve $200 \mathrm{mg} / \mathrm{kg}$ düzeylerinde sarımsak yağı ilavesinin, diyete ilave edilen miktara paralel olarak, karaciğer dokusundaki GTS, GSH-Px, GR ve SOD düzeylerini yükselttiği, MDA ve TBARS değerlerini ise düşürdüğü bildirilmiştir. 


\section{Glutatyon Peroksidaz $(G S H-P x=G-P x)$}

Organizmada biyolojik oksidasyon gibi çeşitli metabolik olaylar sonucu oluşan $\mathrm{H}_{2} \mathrm{O}_{2}$ 'yi suya indirgeyen $\left(\mathrm{H}_{2} \mathrm{O}_{2}+\mathrm{GSH}_{-} \stackrel{\text { G-Px }}{\longrightarrow} \mathrm{GSSH}+2 \mathrm{H}_{2} \mathrm{O}\right)$ ve hidroperoksitlerin indirgenmesini $(\mathrm{ROOH}+2$ $\mathrm{GSH} \stackrel{\mathrm{G}-\mathrm{Px}}{\longrightarrow} \mathrm{GSSH}+\mathrm{ROH}+\mathrm{H}_{2} \mathrm{O}$ ) sağlayan 4 tane Se atomu içeren GSH-Px daha çok stozolik olup mitokondrilerde de düşük miktarlarda bulunmaktadır. GPx aktivitesinde azalma ve hidrojen peroksitlerde artma ile hücre hasarları oluşmaktadır [7]. Tablo 3 incelendiğinde, karma yeme sarımsak tozu ilavesinin araştırmada ele alınan tüm dokularda GSH-Px düzeylerini çok önemli derecede yükselttiği görülmektedir.

Mevcut çalışmada GSH-Px enzimi ile ilgili olarak elde edilen datalar, Itsu ve ark. [22] ratların içme sularına 1g/L sarımsak ekstraktı (Sac) ilavesinin karaciğerde, Ancsin ve ark. [23] broyler yemlerine 25g/kg sarımsak yağı ilavesinin karaciğer ve plazmada, Al-Numair [24] rat diyetlerine 0, 12 ve 24 g/kg sarımsak ekstraktı ilavesinin plazmada, Ghalehkandi ve ark. [25] ratların diyetlerine 0, 60 ve 120 mg/ gün olacak şekilde sarımsak ekstraktı ilavesinin bazı dokularda ve Gong-chen ve ark. [26] yumurta tavuğu yemlerine sırasıyla 0, 50, 10 ve $150 \mathrm{mg} / \mathrm{kg}$ sarımsak ekstraktı (Allisin) ilavesinin karaciğer ve plazmada GSH-Px düzeylerini önemli derecede yükselttiğini gösteren araştırma sonuçlarıyla uyum içerisindedir.

Tablo 3. Grupların Bazı Dokulardaki GSH-Px düzeylerine ait ortalama değerler (U/ml)

\begin{tabular}{|c|c|c|c|c|c|c|}
\hline Gruplar & Kontrol & S 2 & S 4 & S 6 & SEM & $\mathbf{P}$ \\
\hline Karaciğer & $28.02^{C}$ & $30.26^{\mathrm{b}}$ & $31.91^{\mathrm{a}}$ & $32.98^{\mathrm{a}}$ & 0.35 & 0.000 \\
\hline Göğüs & $14.51^{\mathrm{c}}$ & $15.44^{\mathrm{bc}}$ & $16.41^{\mathrm{ab}}$ & $17.01^{\mathrm{a}}$ & 0.34 & 0.001 \\
\hline But & $10.11^{\mathrm{c}}$ & $10.30^{c}$ & $11.15^{\mathrm{b}}$ & $12.81^{\mathrm{a}}$ & 0.12 & 0.000 \\
\hline Serum & $58.81^{\mathrm{c}}$ & $60.31^{\mathrm{b}}$ & $62.17^{\mathrm{a}}$ & $62.22^{\mathrm{a}}$ & 0.35 & 0.000 \\
\hline Yumurta & $3.76^{c}$ & $4.58^{\mathrm{b}}$ & $4.94^{\mathrm{b}}$ & $5.38^{\mathrm{a}}$ & 0.14 & 0.000 \\
\hline
\end{tabular}

\section{Süperoksit Dismutaz (SOD)}

Organizmada endojen olarak üretilen ve organizmayı oluşturan her hücre için esansiyel olan bir metalloenzimdir. Hem stoplazma hem de mitokondride beş farklı formda yer alan bu enzim çok kuvvetli bir serbest radikal olan süper oksit anyonunun $\left(\mathrm{O}_{2}{ }^{-}\right)$hidrojen peroksit ve moleküler oksijene dönüşümünü katalizleyerek sellüler bölmelerdeki süper oksit anyonunun düzeylerini kontrol etmede katkı sağlar $\left(\mathrm{O}_{2}{ }^{-}+\right.$ $\mathrm{O}_{2}{ }^{-}+2 \mathrm{H}^{+} \longrightarrow$ SOD $\quad \mathrm{H}_{2} \mathrm{O}_{2}+\mathrm{O}_{2}$ ) [27]. Mevcut çalışmada incelenen dokulardaki SOD değerleriyle ilgili sonuçların verildiği Tablo 4 incelendiğinde; karma yeme sarımsak tozu ilavesi ele alınan tüm dokulardaki SOD değerlerini çok önemli derecede etkilediği ve ilgili değerlerin yeme ilave edilen sarımsak tozu düzeylerine paralel olarak yükseldiği görülmektedir. Bu çalışmada SOD değerleri ile ilgili olarak elde edilen sonuçlar, Sklan ve ark. [28] yumurta tavuğu yemlerine \%0 ve 2 düzeyinde sarımsak tozu ilave ederek karaciğerde, Metwally [29] balık yemlerine sarımsağın farklı formlarının (sarımsak yağı, sarımsak tozu) ilavesinin plazma ve karaciğerde, Lee ve ark. [30] diyabetli rat diyetlerine \%0 ve 0.5 sarımsak tozu ilavesini plazma ve karaciğerde, Ghalehkandi ve ark. [25] rat diyetlerine 0, 60 ve 120 mg/gün sarımsak ekstraktı ilavesinin karaciğer ve plazmada, Shirzadegan ve Falahpour [31] broyler yemlerine 0, 2.5, 5.0 ve 7.5 g/kg \%45’i sarımsak ekstraktından oluşan (yeşil çay, tarçın, hindiba) ekstraktı karışımı ilavesinin but eti ve karaciğgerde, Gong-chen ve ark. [26] yumurta tavuğu piliç yemlerine 0, 50, 100 ve 150 mg/kg sarımsağın önemli bir komponenti olan Allisin ilavesinin karaciğer ve plazmada SOD değerlerini önemli derecede yükselttiğini rapor eden araştırma sonuçlarıyla benzerlik göstermektedir. 
Tablo 4. Grupların Bazı Dokulardaki SOD düzeylerine ait ortalama değerler (U/ml)

\begin{tabular}{|c|c|c|c|c|c|c|}
\hline Gruplar & Kontrol & S 2 & S 4 & S 6 & SEM & $\mathbf{P}$ \\
\hline Karaciğer & $8.29^{d}$ & $8.99^{c}$ & $10.28^{\mathrm{b}}$ & $12.16^{\mathrm{a}}$ & 0.19 & 0.000 \\
\hline Göğüs & $9.08^{\mathrm{d}}$ & $10.05^{\mathrm{c}}$ & $11.06^{\mathrm{b}}$ & $12.25^{\mathrm{a}}$ & 0.31 & 0.000 \\
\hline But & $10.02^{\mathrm{b}}$ & $10.38^{\mathrm{b}}$ & $10.83^{\mathrm{b}}$ & $12.36^{\mathrm{a}}$ & 0.29 & 0.000 \\
\hline Yumurta & $4.43^{\mathrm{b}}$ & $4.79^{\mathrm{ab}}$ & $4.89^{\mathrm{ab}}$ & $5.37^{\mathrm{a}}$ & 0.20 & 0.039 \\
\hline
\end{tabular}

\section{Katalaz (CAT)}

Demir içeren ve bir metalloenzim olan katalaz dört adet hem grubu ile bir hemoproteinden oluşmaktadır. Özellikle karaciğer ve eritrositlerde bulunan bu enzim süperoksit dismutaz enzimi faaliyeti sonucu oluşan $\mathrm{H}_{2} \mathrm{O}_{2}$ 'i su ve oksijene dönüştürerek etkisiz hale getirir [7]. Bu çalışmada dokulardaki katalaz enzimine ait değerlerle ilgili varyans analiz sonuçları Tablo 5’te verilmiştir.

Tablo 5. Grupların Bazı Dokulardaki CAT düzeylerine ait ortalama değerler (U/ml)

\begin{tabular}{lcccccc}
\hline Gruplar & Kontrol & S 2 & S 4 & S 6 & SEM & P \\
Karaciğer & $475.00^{\mathrm{b}}$ & $404.25^{\mathrm{c}}$ & $472.50^{\mathrm{b}}$ & $526.50^{\mathrm{a}}$ & 12.29 & 0.000 \\
Gögüs & $374.25^{\mathrm{a}}$ & $250.00^{\mathrm{b}}$ & $334.75^{\mathrm{a}}$ & $384.00^{\mathrm{a}}$ & 17.52 & 0.001 \\
But & $304.25^{\mathrm{c}}$ & $331.75^{\mathrm{b}}$ & $340.25^{\mathrm{b}}$ & $366.75^{\mathrm{a}}$ & 5.53 & 0.000 \\
Serum & $238.25^{\mathrm{d}}$ & $294.00^{\mathrm{c}}$ & $361.00^{\mathrm{b}}$ & $387.25^{\mathrm{a}}$ & 6.33 & 0.000 \\
Yumurta & $60.75^{\mathrm{n}}$ & 53.75 & 56.00 & 57.25 & 6.54 & 0.894 \\
\hline
\end{tabular}

Tablo 5 incelendiğinde; karaciğer, göğüs, but ve plazma katalaz düzeylerinin karma yeme sarımsak tozu ilavesinden çok önemli derecede etkilendiği ve ilave edilene düzeye paralel olarak ilgili dokularda katalaz düzeylerinin yükseldiği görülmektedir. Karaciğer, göğüs, but ve plazma katalaz düzeyleriyle ilgili olarak elde edilen veriler, Hsu ve ark. [22] ratların içme suyuna 0 ve $1 \mathrm{mg} / \mathrm{L}$ sarımsak ekstraktı bileşeni s- allil sistein (SAC) ilavesinin karaciğer ve böbrek dokusunda, Lee ve ark. [30] rat diyetlerine \%0 ve 0.5 sarımsak tozu ilavesinin karaciğer ve plazmada, Metwally [29] balık yemlerine farklı formlarda sarımsak ilavesinin karaciğer ve plazmada, Ghalehkandi ve ark. [25] yine rat diyetlerine 0, 60 ve 120 mg/gün sarımsak ekstraktı ilavesinin antioksidan mekanizmasını pozitif yönde etkilediği ve plazma katalaz düzeylerini yükselttiğini bildiren çalışmalarla uyum içerisinde olmakla birlikte, karma yeme sarımsak tozu ilavesi istatistiksel olarak önemli bulunmasa da, yumurta sarısı katalaz düzeylerini düşürdüğü saptanmıştır. Bu sonuç; karma yeme ilave edilen sarımsak tozunun içeriğinde bulunan organosülfür bileşiklerinin (SAC, DAS, DADS ve Allisin vb) plazmada demiri bağlayarak [32] zaten düşük düzeyde (1 mg/yumurta) demir içeren [33] yumurtaya, aktivitesi için demire ihtiyaç duyan katalaz enziminin ihtiyaç duyduğu miktarda demir geçememesi sonucu katalaz düzeyinin azaldığı düşünülmektedir.

\section{Sonuç}

Gerek yapılmış mevcut çalışma, gerekse konuyla ilgili olarak daha önce yapılmış diğer araştırmaların sonuçları sarımsağın önemli bir doğal antioksidan etkiye sahip olduğunu göstermektedir. Sarımsak bu antioksidan etkisini, bünyesinde bulunan ve kuru maddesinin \%33’ünü oluşturan organosülfür bileşikleri, tiyol gruplarını kolayca serbest radikallere vererek onları düşük aktiviteli bileşiklere dönüştürüp toplayıcı etki yaparak [14] antioksidan savunma havuzunda antioksidan enzimlerin kullanımını azaltıp onların düzeylerinin yükselmesini sağlamak suretiyle gösterdiği söylenebilir. Tiyol 
grupları serbest radikallerle reaksiyona girerek onları etkisiz hale getirip organizmada antioksidanların düzenlenmesinde rol oynarlar [34].

Keza, serbest demir iyonları $\left(\mathrm{Fe}^{+2}\right)$ canlı sistemde serbest radikal oluşturan güçlü bir oksidatif katalist olarak görev yapmaktadır. Serbest demir iyonları hidrojen peroksiti daha çok reaktif bir radikal olan hidroksil $\left(\mathrm{OH}^{-}\right)$radikaline çeviren Fenton-tip reaksiyonları katalize etmektedir. $\mathrm{OH}$ radikali oldukça reaktif bir tür olup çok hızlı bir şekilde lipit radikallerini oluşturarak lipit peroksit zincir reaksiyonlarını başlatmaktadır [35]. Sarımsakta bulunan çok sayıdaki organosülfür bileşikleri plazmadaki serbest demiri bağlayıp [32] böyle güçlü bir radikalin üretimini azaltarak antioksidan savunma havuzundaki antioksidan enzimlerin düzeylerinin yükselmesine destek olduğu söylenebilir.

\section{Kaynaklar}

[1] Çelebi Ş., "Yumurta tavuğu rasyonlarına geç dönemde hayvansal ve bitkisel yağ ilavesinin performans, yumurta kalitesi ve yumurta sarısı yağ asidi kompozisyonu üzerine etkileri” Atatürk Üniversitesi, Fen Bilimleri Enstitüsü, Doktora Tezi, Erzurum, 2003.

[2] Altop A., Erener G., "Kanatlılarda serbest radikal oluşumu lipid oksidasyonu ve antioksidanlar arasındaki ilişkiler" V. Ulusal Hayvan Besleme Kongresi, 30 Eylül-3Ekim, Çorlu/Tekirdağ, 2009.

[3] Çavdar C., Sifil A., Çamsarı T., "Reaktif oksijen partikülleri ve antioksidan savunma” Türk Nefroloji Diyaliz ve Transplantasyon Dergisi, 3-4, 92-95, 1997.

[4] Halliwell B., "Drug antioxidant effects: A basis for drug selection?” Drugs, 42(4), 569-605, 1991.

[5] Avanzo J.L., de Mendonça C.X. Jr., Puqine, S.M., Cerqueira Cesar M., "Effect of vitamin E and selenium on resistance to oxidative stress in chicken superficial pectoralis muscle" Comp. Biochem. Physiol. C. Toxicol. Pharmacol., 129(2), 163-73, 2001.

[6] Kilinç K., "Oxygen radicals: their production, function and toxic effects” Biyokimya Dergisi, 9, 59-76, 1986.

[7] Çaylak E., "Hayvan ve bitkilerde oksidatif stres ile antioksidanlar" Tip Araştırmaları Dergisi, 9(1), 73-83. 2011.

[8] Demirel R., Alınca S., Demirel S.D., "İnsan ve hayvan beslenmesinde antioksidanlar” 6. Ulusal Zootekni Kongresi, 24-26 Haziran, Erzurum, 2009.

[9] Akkuş İ., "Serbest radikaller ve fizyolojik etkileri”. Mimoza Yayınları, Konya,1995.

[10] Halliwell B., Gutteridge, J., "Free Radicals in Biology and Medicine”. 2nd Edition, Clarendon Press, Oxford, 1996.

[11] Saçıldı E., Öztürk E., "Yıllanmış sarımsak ekstraktının kanatlı hayvan performansı üzerine etkileri” 8. Ulusal Zootekni Öğrenci Kongresi, 22-23 Mayıs, Şanlıurfa, 2012.

[12] Canoğulları S., Karaman M., Erdoğan Z., Baylan M., Küçükgül A., Düzgüner V., Özgür K., "Yumurtacı tavuklarda sarımsak tozunun performans yumurta sarısı kolesterolü ve bazı biyokimyasal parametreler üzerine etkisi” V. Ulusal Hayvan Besleme Kongresi, 30 Eylül-3 Ekim Çorlu/Tekirdağ, 2009. 
[13] Amaqase H., Petesch B.L., Matsuura H., Kasuqa S., Itakura Y., "Intake of garlic and its bioactive components” Journal of Nutrition, 131(3), 955-962, 2001.

[14] Colin-Gonzalez A.L., Santana R.A., Silva-Islas C.A., Chanez-Cardenas M.E., Santamaria A., Maldonado P.D., "The antioxidant mechanisms underlying the aged garlic extract and sallylcysteine induced protection”, Oxidative Medicine and Cellular Longevity, http://dx.doi.org/10.1155/2012/907162, 2012.

[15] Kaya H., "Farklı seviyelerde sarımsak tozunun ve bakırın yumurtacı tavuklarda performans, yumurta kalitesi ve lipid metabolizması üzerine etkileri” Atatürk Üniversitesi, Fen Bilimleri Enstitüsü, Doktora Tezi, Erzurum, 2008.

[16] Aktaş E., "Ratlarda parasetamol ile oluşturulan hepatoksisite üzerine taraxacum officinale etanol ekstraktının etkisi” Atatürk Üniversitesi, Sağlık Bilimleri Enstitüsü, Yüksek Lisans Tezi, Erzurum, 2014.

[17] SPSS, “SPSS for Windows Release 10.0” SPSS Inc. Chicago, 1999.

[18] Boyer T.D., “The glutathione S-transferases: an update” Hepatology, 9(3), 486-96, 1989.

[19] Ar1 F., Dere E., “Benzen'in karaciğer glutatyon s-transferaz enzim aktivitesine in vitro etkisi” Cumhuriyet Üniversitesi Fen Fakültesi Fen Bilimleri Dergisi, 24(1), 76-81, 2003.

[20] Koç S., Alptekin D., “Glutatyon S-transferaz genindeki delesyonların (GSTT1 ve GSTM1) koroner arter hastalığı ve akut miyokart infarktüsü ile ilişkisi” Çukurova Medical Journal, 39(2), 256-261, 2014.

[21] Sheen L.Y., Chen H.W., Kung Y.L., Liu C.T., Lii C.K., "Effects of garlic oil and its organosulfur compounds on the activities of hepatic drug-metabolizing and antioxidant enzymes in rats fed high- and low-fat diets” Nutr Cancer. 35(2),160-166, 1999.

[22] Hsu, C.C., Huang C.N., Hung Y.C., Yin M.C., "Five cysteine-containing compounds have antioxidative activity in Balb/cA mice” Journal of Nutrition, 134(1), 149-152, 2004.

[23] Ancsin Z., Erdeli M., Mezes M., "Effect of rosemary and garlic oil supplementation on glutathione redox system of broiler chickens” Acta Biologica Szegediensis, 53(Suppl.1), 2009.

[24] Al-Numair K.S., "Hypocholesteremic and antioxidant effects of garlic (allium sativum l.) extract in rats fed high cholesterol diet” Pakistan Journal of Nutrition, 8(2), 161-166, 2009.

[25] Ghalehkandi J.G., Ebrahimnezhad Y., Sis N.M., "The effect of aqueous garlic extract and chromium chloride complement on tissue anti oxidant system of male rats” Journal of Animal and Plant Sciences, 23, 56-59, 2013.

[26] Gong-Chen W., Lu-lu H., Jing W., Wan-nan L. Chan-yi P., Yan-fei L., "Effects of allicin on lipid metabolism and antioxidant activity in chickens” Journal of Northeast Agricultural University (English Edition), 21(3), 46-49, 2014.

[27] Aliakbar, S., Brown, P.R., Bidwell, D., Nicolaides, K.H., 1993. Human erythrocyte superoxide dismutase in adults, neonates, and normal, hypoxaemic, anaemic, and chromosomally abnormal fetuses. Clin Biochem., 26(2):109-15.

[28] Sklan D., Berner Y.N., Rabinowitch H.D., “The effect of dietary oninon and garlic on hepatic lipid concentrations and activity of antioxidative enzymes in chick" Journal of Nutritional Biochemistry, 3, 322-325, 1992. 
[29] Metwally M.A.A., "Effects of Garlic (Allium sativum) on Some Antioxidant Activities in Tilapia Nilotica (Oreochromis niloticus)” World Journal of Fish and Marine Sciences, 1(1), 56-64, 2009.

[30] Lee Y.M., Gweon O.C., Seo Y.J., Im J., Kang M.J., Kim M.J., Kim J.I., “Antioxidant effect of garlic and aged black garlic in animal model of type 2 diabetes mellitus” Nutr Res Pract., 3(2),156-61, 2009.

[31] Shirzadegan K., Falahpour P., "The physicochemical properties and antioxidative potential of raw thigh meat from broilers fed a dietary medicinal herb extract mixture” Open Veterinary Journal, 4(2), 69-77, 2014.

[32] Dairam A., Fogel R., Daya S., Limson J.L., “Antioxidant and iron-binding properties of curcumin, capsaicin, and S-allylcysteine reduce oxidative stress in rat brain homogenate" Journal of Agriculture and Food Chemistry, 56(9), 3350-3356, 2008.

[33] Aksoy A., Macit M., Karaoğlu, M., “Hayvan Besleme” Atatürk Üniv. Ziraat Fak. Ofset Tesisleri, Erzurum, 2000.

[34] Başkol M., Başkol G., Koçer D., Artış T., Yılmaz Z., "Mide kanserli hastalarda oksidan ve antioksidan parametreler ve birbiriyle ilişkileri” Türk Klinik Biyokimya Dergisi, 5(3), 83-89, 2007.

[35] Koca N., Karadeniz F., "Serbest radikal oluşum mekanizmaları ve vücuttaki antioksidan savunma sistemleri” Gıda Mühendisliği Dergisi, 16, 32-37, 2003. 